The effect of aeration on the distribution of microalgae ... (Ludi Parwadani Aji)

\title{
THE EFFECT OF AERATION ON THE DISTRIBUTION OF MICROALGAE CONCENTRATE
}

\author{
Ludi Parwadani Aji \\ Technical Implementation Unit For Marine Life Conservation, Research Centrefor Oceanography, \\ Indonesian Institute of Science (LIPI)
}

(Received 6 Juni 2011; Accepted 22 September 2011)

\begin{abstract}
Microalgae concentrates (paste) can be used as an alternative feed to replace live microalgae for aquaculture due to its nutritional value and convenience. However, the clumping of cells and negative buoyancy of algae concentrate can affect bivalve culture as bivalves only capture particles suspended in the water and ingest a certain size range of particles. This study investigated the effects of aeration on the distribution of algae particles in a $500 \mathrm{~L}$ rearing tank. The results indicated that the number of algae paste particles was higher in the aerated tanks compared to the non- aerated tanks over 24 hours. Time lapsed had a significant effect on the number of particles after the addition of algae concentrate into the tanks. The number of particles in the aerated and non-aerated tank was relatively stable from 1 to 10 hours and then declined after 24 hours. Furthermore, tank depth had no significant effect on the number of particles distributed as the number of particles did not differ significantly at three different depths within the culture tanks.
\end{abstract}

KEYWORDS: microalgae concentrate, depth, time, particle

\section{INTRODUCTION}

Microalgae are currently used as a food source in aquaculture because of their high nutritional value (Duerr et al., 1998, Becker, 2004, Martínez- Fernández et al., 2004, Ponis et al., 2006b) and because it is the natural food of many cultured animals (Borowitzka, 1997). Moreover, their physical characteristics such as cell size, thickness of cell wall, digestibility, presence of spiny appendages and chain formation (e.g. diatoms) all influence the suitability of microalgae as food used in aquaculture (Kach and Ward, 2008). For example, their cell size and nutritional value are suitable for larvae and adult bivalves, the larvae of other molluscs, crustacean and fish, or as feed for the live prey used in culturing, such as roti- fers and brine shrimp (Artemia) (Langdon, 2003, Becker, 2004, Ponis et al., 2006a, Holme et al., 2009). Furthermore, the content of fatty acids, proteins (amino acids), lipids, vitamins and carbohydrates of various microalgae species is one of the main reasons for considering these organisms as a feed source for aquaculture animals (Knauer and Southgate, 1999).

Recently, algae concentrate as also known as algae paste (nonviable algae) has become commercially available and is starting to be widely used. For example, commercially available algae concentrate ('Instant Algae' products) has been used for laboratory culture of juvenile and adult shellfish (Ingersoll et al., 2006, Wang et al., 2007). Furthermore, the simple and inexpensive use of algae concen-

\# Corresponding author. Research Centre for Oceanography, Indonesian Institute of Science (LIPI), Biak - Papua Barat, Indonesia

E-mail address: ludi_bio@yahoo.co.id 
trate as a food source is suitable for the production of rotifer Brachionus plicatilis (Pfeiffer and Ludwig, 2007) and Artemia (Palmtag et al. 2006). Algae concentrates have also been used in the culture of fish larvae (Joan Holt et al., 2007) and shrimp (Zelaya et al., 2007). In spite of these positive results, research on the best procedures to prepare algae concentrates for use, i.e., to optimise the proportion of particles within an appropriate size range and maintain their availability in the water column is required.

The drawback of using algae concentrates is that the cells have lost motility and it becomes difficult to disaggregate back to single cells which is a requirement for feeding bivalves (Knuckey et al., 2006). Hence, the size of particles within algae concentrates is bigger when added into the water than that of live algae and therefore more difficult to be ingested by larvae. Moreover, as the behaviour of algae concentrate in the water column differs from that of live algae (which have motility), this may affect the ability of cultured animals, especially bivalves, to feed on algae concentrates. Bivalves practise suspension filter feeding animals as the gills with their different ciliary tracts remove suspended particles from the water as it is pumped through the mantle cavity (Cognie et al., 2003).

Even though the trend is increasingly towards the use of microalgae concentrates for the rearing of larvae or juvenile bivalves, there remains the disadvantage of concentrate settling to the bottom of rearing tanks where decomposition can lead to an unhealthy environment and possibly disease (Backhurst et al., 1989). If microalgae concentrates is to be fully exploited, there is an important need for information on the availability and distribution of microalgae concentrate cells in order to ensure that all the food is available for bivalves at all times. Therefore, the objective of this study was to determine the distribution of algae cells prepared from al gae concentrates in $500 \mathrm{~L}$ rearing tanks of bivalve larvae when aerated, and at different depth and times.

\section{MATERIALS AND METHODS}

\section{Effect of Aeration on The Distribution of Algae Concentrate}

This experiment used alga suspensions made from paste Pavlova and Isochrysis. The $10 \mathrm{~mL}$ algae paste was mixed with $1 \mathrm{~L}$ filtered
$(1 \mu \mathrm{m})$ seawater and prepared by shaking the bottle 15 times. Cylindrical rearing tanks for bivalve larvae made from fiberglass with one meter diameter and $80 \mathrm{~cm}$ deep were used in this study (Figure 1). Before any test was carried out, the tanks were washed with chlorine (bleached) and cleaned. The tanks were then flushed with freshwater to remove all contaminants. After this, the tanks were rinsed with filtered $(1 \mu \mathrm{m})$ seawater and the seawater was run for some considerable time to remove all particles and to ensure that it was perfectly clean. In the centre of the tanks, a stand pipe was attached to support a $4 \mathrm{~mm}$ plastic tube used to remove the water samples used in this analysis and attached to the stand pipe at three different depths using clips. The tanks were then filled with approximately $450 \mathrm{~L}$ with filtered $(1 \mu \mathrm{m})$ seawater at ambient temperature.

Tests were carried out in aerated and nonaerated tanks with three replications for each treatment. For aerated tanks, air was added into the tanks from an aeration tube on the bottom of the tank (figure 1 ) at a rate of $150 \pm 10 \mathrm{~mL}$ per minute; it was placed around $30 \mathrm{~cm}$ from the stand pipe. The air was filtered by a series of cartridge filters of decreasing porosity. This was needed to reduce airborne contaminants that may contain harmful micro- organisms. The $1 \mathrm{~L}$ of algae suspension (see above) was poured gently across the surface of the water. After addition of the suspension, water samples

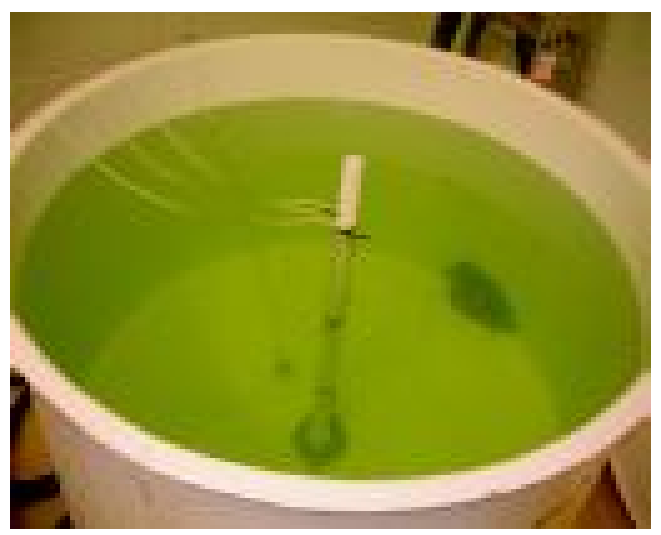

Figure 1. The $500 \mathrm{~L}$ tank for bivalve larvae rearing used to examine the effect of aeration on algae concentrate. Stand pipe attached in the bottom to support plastic tube which was used to take water sample from shallow, middle and deep areas 
The effect of aeration on the distribution of microalgae ... (Ludi Parwadani Aji)

were then collected four times; 1 hour, 5 hours, 10 hours and 24 hours after the addition from 3 fixed points in the tanks, which were 10- 15 cm (deep), 30- $40 \mathrm{~cm}$ (middle) and 55- 65 (shallow) from the bottom. This was done by siphoning and the sampling tube was allowed to flush before a water sample was collected in a 70 $\mathrm{mL}$ sample bottle. The first seawater that was poured into the bottle sample was used to rinse the bottle sample. The water temperature was also checked every time samples were collected. Samples were analyzed using the FlowCam machine to determine algae cell sizefrequency distribution (Sieracki et al., 1998).

\section{Statistical Analysis}

For the study on the distribution of algae concentrate in the tanks, ANOVA was used to determine if there were any differences in the number of particles (response variable) between aerated and non aerated tanks. Moreover, a full cross factorial test was used to examine the number of particles in response to explanatory variables such as hours, depth and the interaction of aeration $\mathrm{x}$ hour, aeration $x$ depth, aeration $x$ hour $x$ depth. Post hoc comparison was conducted using a Tukey multiple comparison (pairwise) to determine significant differences among the treatments. For all tests, an alpha level of 0.05 was used.

\section{RESULTS AND DISCUSSION}

\section{Results}

\section{Isochrysis}

There were significantly more particles in the aerated tanks $(11608.41 \pm 538.78)$ than in the non-aerated tanks (10485.83 \pm 524.99$)$ (Figure 2) $\left(F_{14}=9.45, P=0.037\right)$. In addition, the time after addition of the algae suspension into the tanks also had a significant effect on the number of particles $\left(\mathrm{F}_{3,44}=7.6, \mathrm{P}<0.001\right)$. The number of particles increased gradually from 1 to 10 hours before declining after 24 hours both in aerated and non- aerated tanks. There was no significant interaction between aeration and time after addition of algae suspension $\left(F_{3,44}=0.56, P=0.64\right)$. The highest number of particles was recorded 10 hours after the addition of algae suspension in the tanks (13578.77 \pm 925.27$)$ and this was statistically different to all other duration treatments. The fewest number of particles was found after 24 hours (9294.61 \pm 429.25$)$ but the difference was not significant from the number of particles after 1 hour (10378.22 \pm 541.05$)$ and 5 hour (10936.88 \pm 697.48$)$ treatments.

The depth at which samples were taken within the tanks had no significant effect on the number of particles recorded $\left(\mathrm{F}_{2,44}=0.09\right.$,

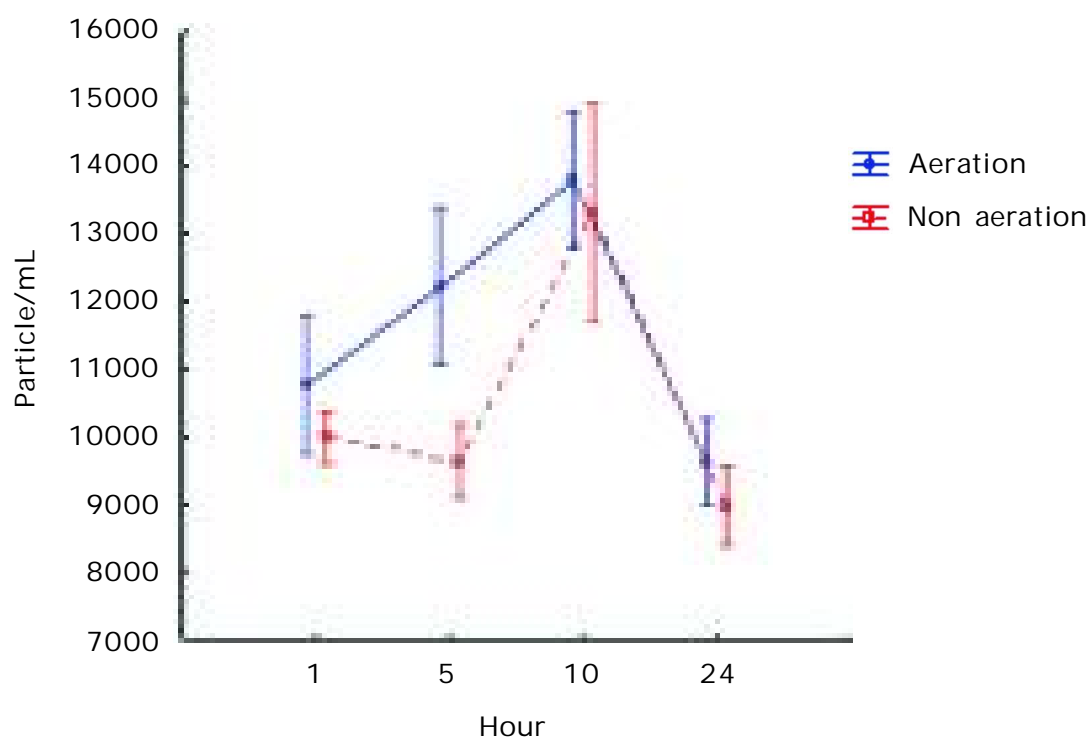

Figure 2. Changes in the number of particles per $\mathrm{mL}$ in the aerated and nonaerated $500 \mathrm{~L}$ tanks following the addition of algae suspension prepared from Isochrysis concentrate 
$\mathrm{P}=0.914$ ), and the interaction between aeration and depth were marginally non- significant $\left(F_{2,44}=3.16, P=0.052\right)$ (Figure 3). The highest number of particles in aerated tanks was found at greatest depth and the fewest was in the middle area. However, in the non- aerated tanks, the highest number of particles was found in the middle area and the fewest in the bottom area. The interaction terms between depth and duration since the addition of the algae suspension $\left(F_{6.44}=0.61, P=0.72\right)$ and the interaction of aeration, depth and duration $\left(F_{6,44}=1.84\right.$, $\mathrm{P}=0.114$ ) were not- significant (Figure 4). The water temperature inside the tank over 24 hours was stable at $27 \stackrel{\circ}{\circ} \pm 1 \stackrel{\circ}{ }$.

\section{Pavlova}

In contrast to the results obtained for the Isochrysis suspension, no significant differences were observed in the number of particles in the aerated or non- aerated tanks for Pavlova $\left(F_{1,4}=5.98, P=0.071\right)$ (Figure 5). However, the number of particles in the aerated tanks was higher than that of non- aerated tanks. There was a significant interaction between aeration and time since addition of algae suspension in the number of particles $\left(F_{3,44}=3.18, P=0.033\right)$. The number of particles after 1,5 and 10 hours was quite similar both in the non- aerated and aerated tanks. Similarly, the time after the addition of algae suspension had a significant effect on the number of particles $\left(\mathrm{F}_{3,44}=45.47, \mathrm{P}<0.001\right)$. The number of particles in the aerated and non- aerated tanks tends to be stable from 1 to 10 hours and then declined after 24 hours. The number of particles of algae after 24 hours (8765.50 \pm 506.93$)$ was significantly lower compared to 1,5 and 10 hours.

Depth of the tanks had no significant effect on the number of particles $\left(F_{2,44}=0.21\right.$, $\mathrm{P}=0.81$ ) as the number of particles was similar in all three depths (Figure 6). Furthermore, there was no interaction effect between aeration and depth $\left(F_{2,44}=0.80, P=0.45\right)$. However, the number of particles in the deep area with aeration was the highest, while in the nonaerated tank was the lowest compared to the middle and shallow area. There was no interaction effect between depth and time $\left(F_{6.44}=0.89, P=0.50\right)$ (Figure 7). Similarly, no interaction of aeration $\mathrm{x}$ depth $\mathrm{x}$ time effect $\left(F_{6,44}=0.98, P=0.44\right)$ were observed for the number of particle. The water temperature inside the tank over 24 hours was maintained at 27 $\stackrel{\circ}{\circ} \pm 1 \stackrel{\circ}{\circ}$.

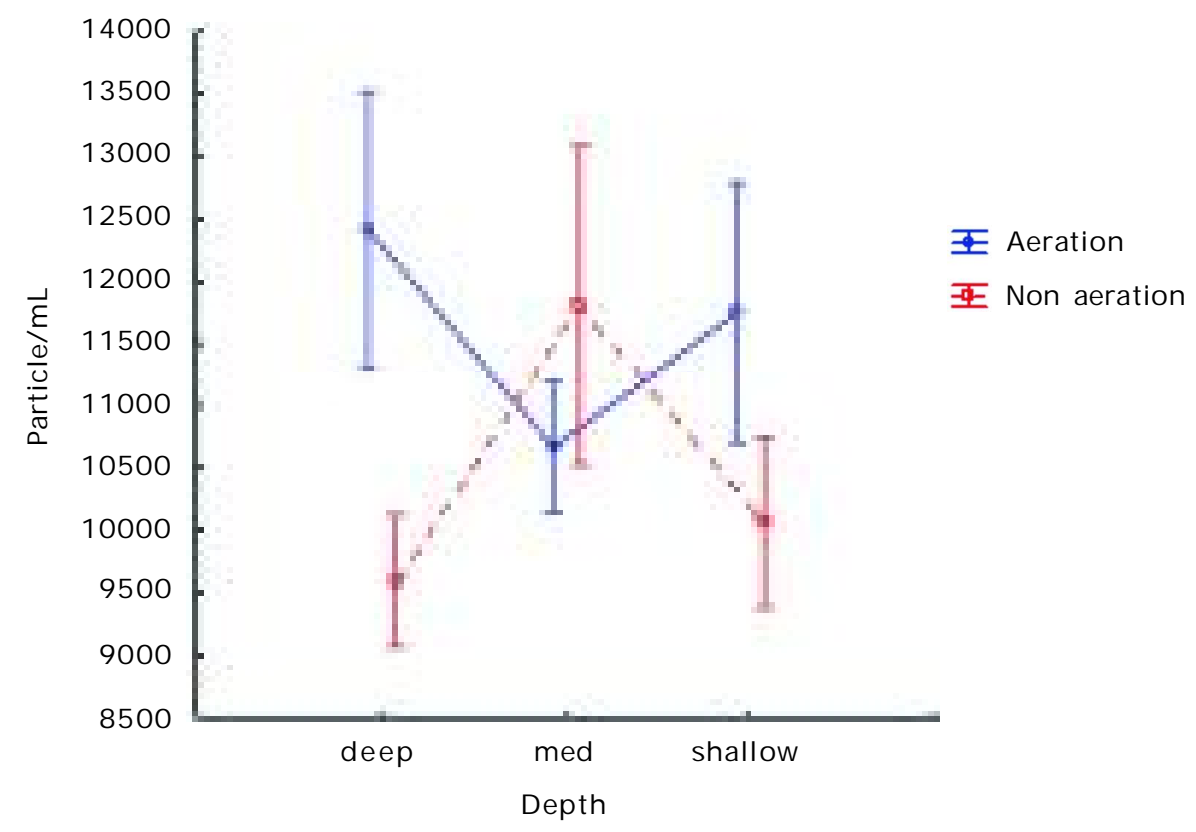

Figure 3. Changes in the number of particles per $\mathrm{mL}$ in the aerated and non- aerated $500 \mathrm{~L}$ tanks following the addition of algae suspension prepared from Isochrysis concentrate at three different depths (deep, medium, shallow) 
The effect of aeration on the distribution of microalgae ... (Ludi Parwadani Aji)

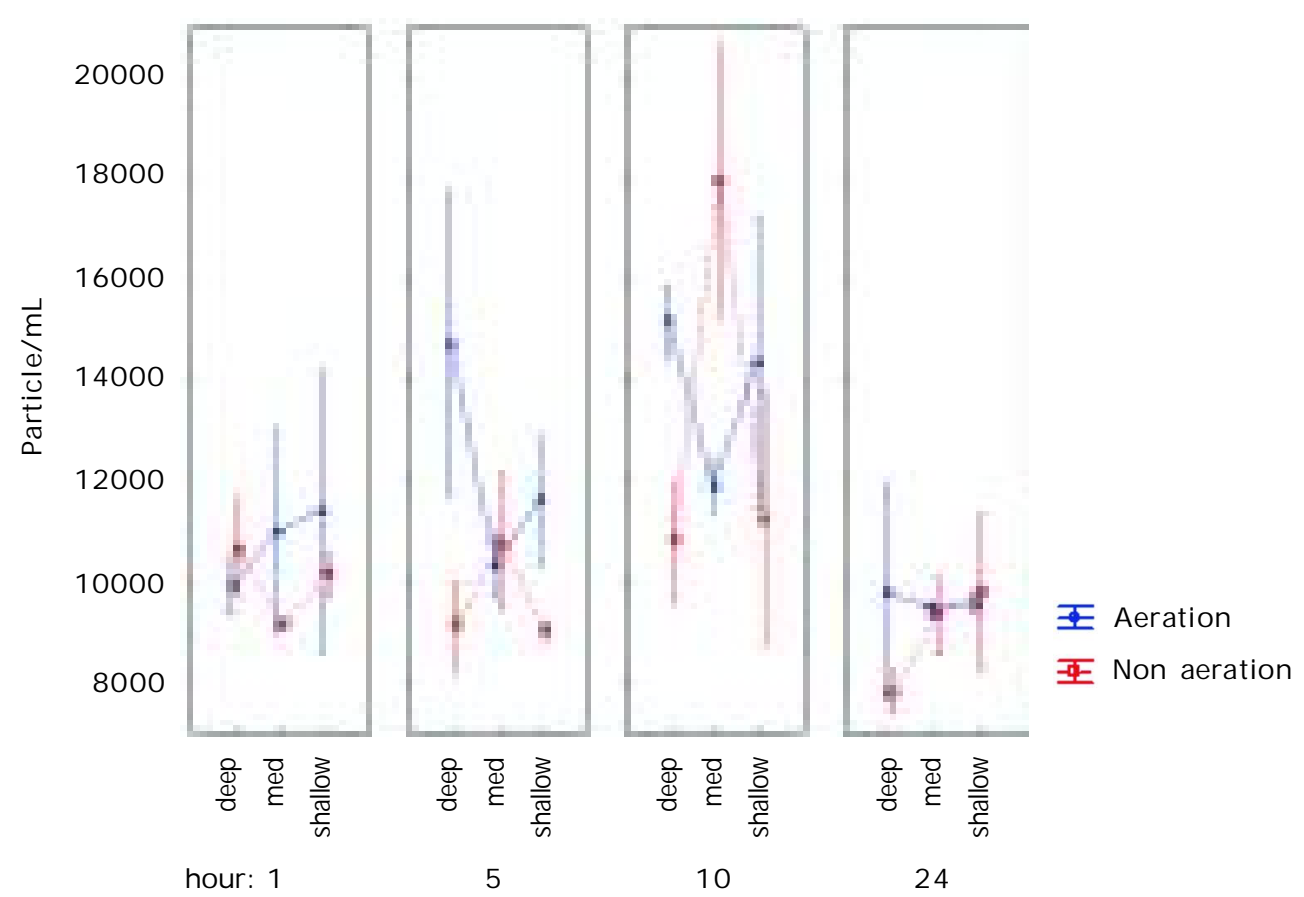

Figure 4. Changes in the number of particles per $\mathrm{mL}$ in the aerated and non-aerated $500 \mathrm{~L}$ tanks following the addition of algae suspension prepared from Isochrysis concentrate at three different depths (deep, medium, shallow) over 24 hours

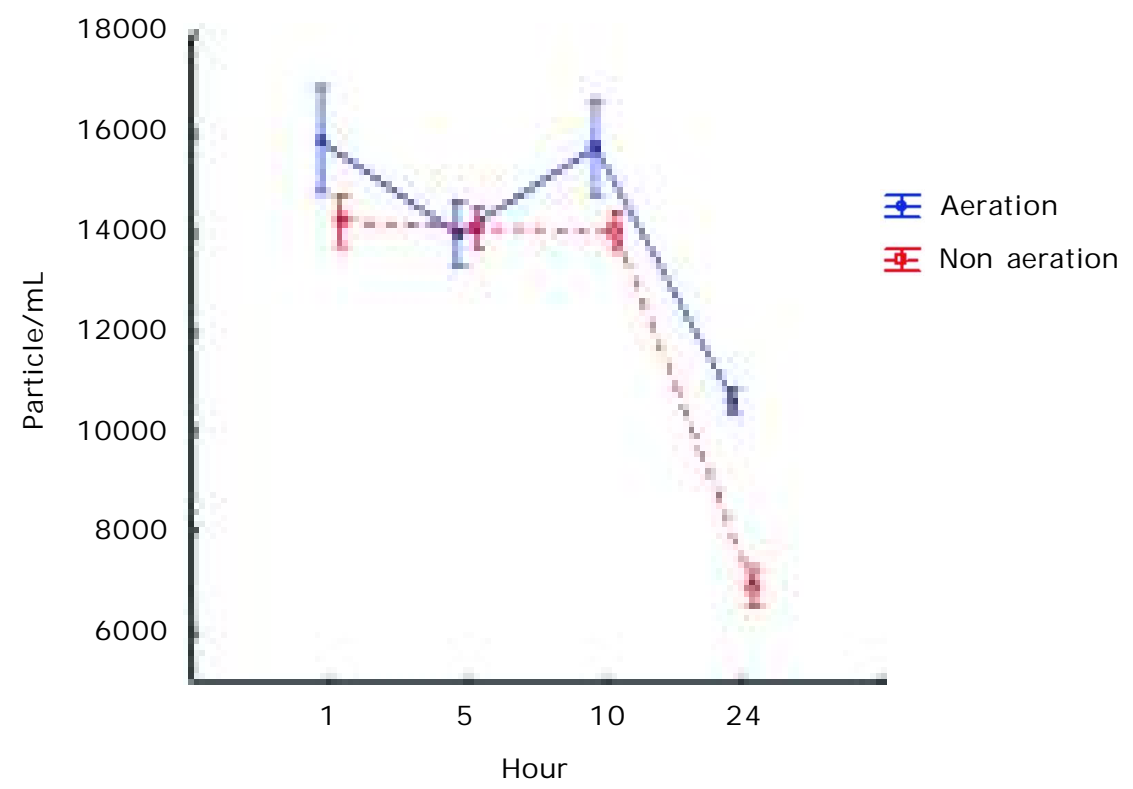

Figure 5. Changes in the number of particles per $\mathrm{mL}$ in aerated and nonaerated $500 \mathrm{~L}$ tanks following addition of algae suspension prepared from Pavlova concentrate 
Indonesian Aquaculture Journal Vol.6 No.2, 2011

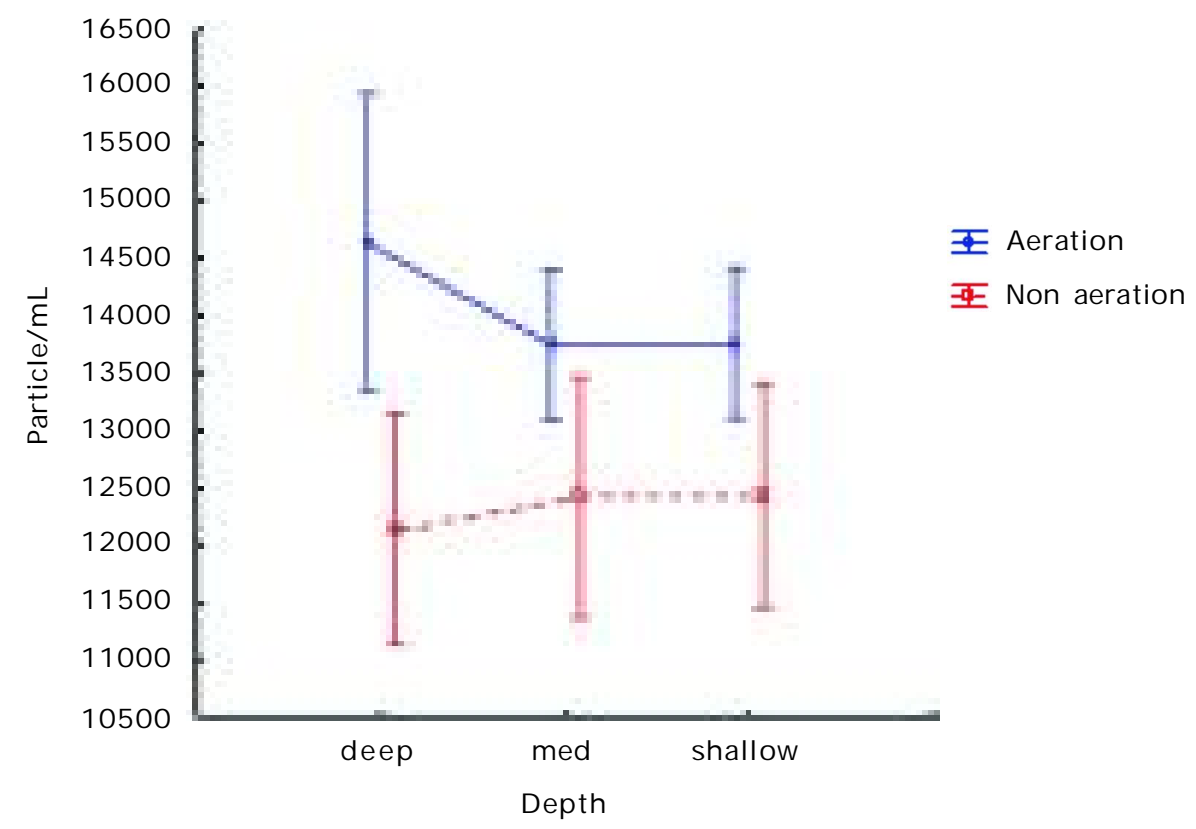

Figure 6. Changes in the number of particles per $\mathrm{mL}$ in the aerated and non- aerated $500 \mathrm{~L}$ tanks following the addition of algae suspension prepared from Pavlova concentrate at three different depths (deep, medium, shallow)

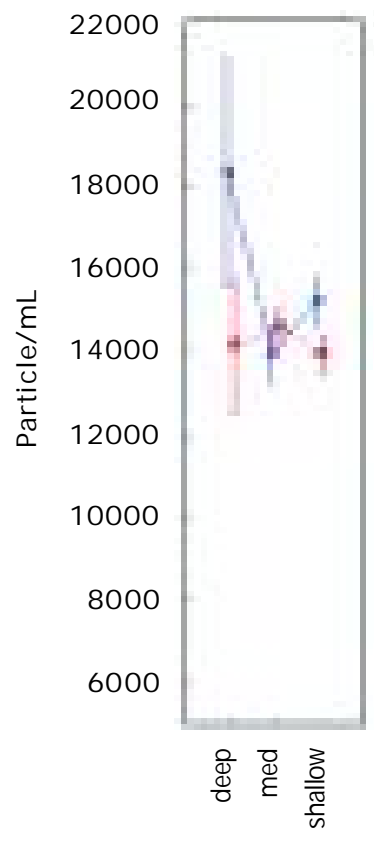

hour: 1

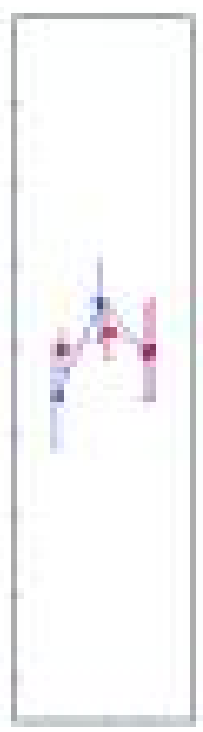

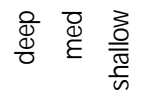

5

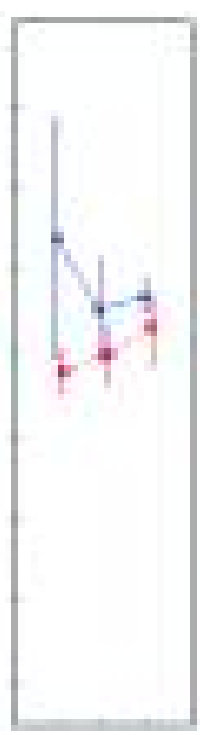

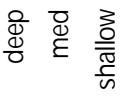

10

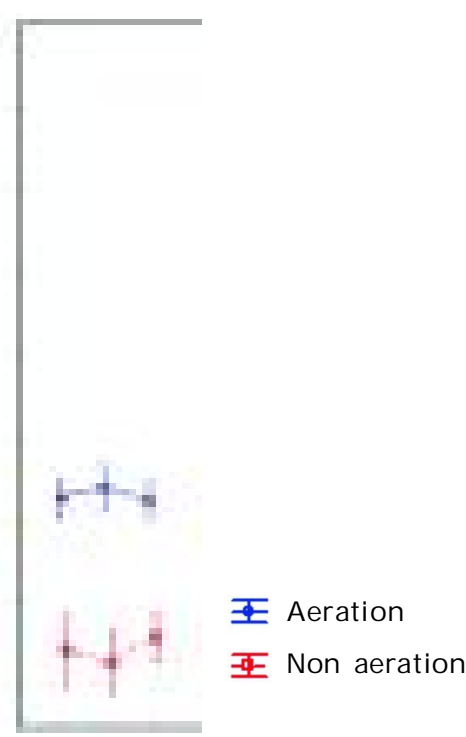

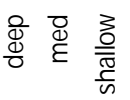

24

Figure 7. Changes in the number of particles per $\mathrm{mL}$ in the aerated and non- aerated $500 \mathrm{~L}$ tanks following the addition of algae suspension prepared from Pavlova concentrate at three different depths (deep, medium, shallow) over 24 hours 


\section{Discussions}

The results showed that the number of particles of microalgae concentrate (Isochrysis and Pavlova) in the aerated tanks was higher than that of non- aerated tanks over 24 hours. This is because aeration breaks the clumping of algae concentrate and results in disaggregating the cells. According to Riebesell (1991), turbulent energy in the water column can become the dominant mechanism controlling both particle aggregation and break up. As the air flow is increased, the number of particles in suspension is also increased. While, very low air flows reflecting the very few particles which are in suspension because the mass of particles collected is very low.

The number of algae cells in the thanks receiving suspensions prepared from Pavlova tended to be stable while for Isochrysis, it increased gradually from 1 to 10 hours after the addition of algae concentrate before declining after 24 hour both in the aerated and non- aerated tanks. The algae concentrate of Pavlova may be easily broken up by the treatment while Isochrysis needs time to be broken up after they were put in the seawater. Following that, the number of particles at 24 hour in the non- aerated tanks was lower than that of the aerated tanks. In non- aerated tanks, somewhat unexpectedly, the clumps of particles may move slowly around the bottom of the walls of the tank. Visual observation of nonaerated tanks showed that particles were stationary at the base and began to clump on day

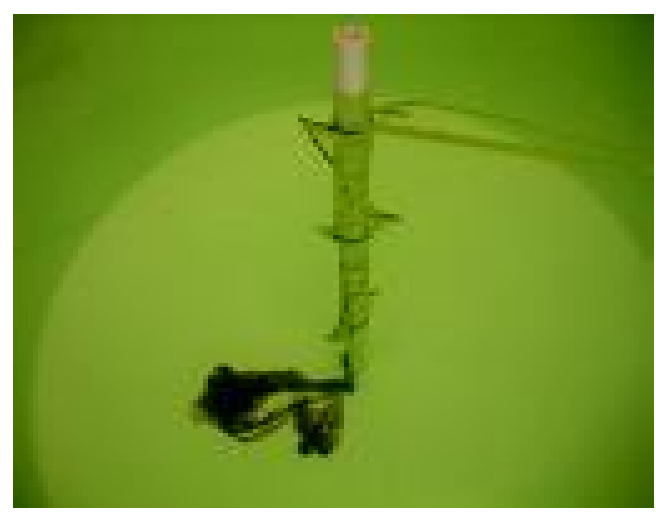

Figure 8. Visual observation in the non aerated tank after 2 days of algae concentrate addition showing large masses of clumped algae cells
2 (Figure 8) and the water became very clear after day 7 (Figure 9). While, in the aerated tanks, few aggregations occurred on the pipe or plastic tube and mostly the particles were dispersed in the water at all time from day 1 , day 2 (Figure 10) and day 7 . It seems that without aeration the particles of algae concentrate tend to settle down to the base of the tank where they formed large clumps and were unavailable as food particles.

As microalgae particles settle on the bottom of the tanks, aeration is important to maintain this algae particles in the water column. It is essential to keep the algae particles in suspension because bivalves will only feed on suspended material and any food falling to the bottom of the culture tanks will be decomposed and deteriorate the water, lead to an unhealthy environment and possibly disease (Backhurst et al., 1989). The clumping of algae concentrate particles settling in the bottom of the tank was found in the non aerated tank (Figure 8 and 9). The large clumping of algae concentrate may be affected by biological activity (Alldredge \& Silver, 1988), since it has been observed in the field that during diatom blooms, mass flocculation of the algae results in the formation of large aggregates (Alldredge \& Gotschalk, 1989).

With respect to the effect of depth, the number of algae concentrates Isochrysis particles in the deep, middle and shallow areas of aerated tank were higher than that of the non aerated tank, while the pattern for

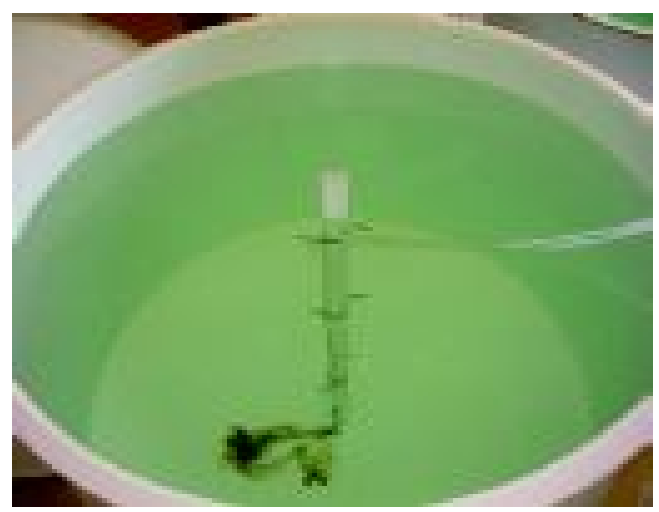

Figure 9. Visual observation in the non aerated tank after 7 days of algae concentrate addition, showing large masses of clumped algae cells and very clear water 


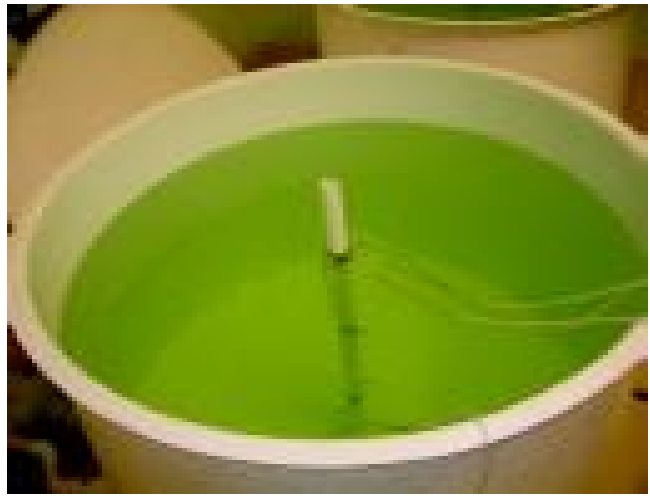

Figure 10. Visual observation in the aerated tank after 2 days of algae concentrate addition showing no clumping or aggregation of algae cells

Pavlova differed in that there were more particles in the deep and shallow areas but lower in the middle of aerated tank than that of the non- aerated tank. However, there were no significant differences in the number of particle distribution at the three different depths over 24 hour. Aeration is required to provide adequate mixing of algae concentrate in the suspension and ensure uniform condition in a tank at all times (Backhurst and Harker, 1988b). The suspension of algae concentrate particles was better in the aerated tank than that of non aerated tank due to more particles and particles appeared to be evenly distributed throughout the water column. In the tanks used for rearing of bivalves, air is eminent not only to break up clumping of particulate food but also to maintain dissolved oxygen at sufficient levels to support living organisms. Moreover, the air can displace waste gases and keep carbon dioxide concentration at an acceptable level (Backhurst and Harker, 1988a).

\section{CONCLUSION}

Aeration is needed to prevent clumping of algae particles and maximize its availability to larval bivalves. For further research, there is an important need for aeration data to identify more precisely the levels of aeration for such particles to be maintained in the water column to ensure available food for bivalves and a healthy growing environment at all times. The minimum degree of aeration which provides adequate circulation levels such that food is always kept in suspension is important to reduce the operational cost.

\section{REFERENCES}

Alldredge, A.L., Gotschalk, C.C. 1989. Direct observations of the mass flocculation of atom blooms: characteristics, settling velocities and formation of diatom aggregates. Deep Sea Res., 36(2): 159- 171.

Alldredge, A.L. \& Silver, M.W. 1988. Characteristics, dynamics and significance of marine snow. Prog. Oceanogr., 20: 41- 82.

Backhurst, J.R. \& Harker, J.H. 1988a. The settling rates of larval feeds. Aquacultural Engineering, 7: 363- 366.

Backhurst, J.R. \& Harker, J.H. 1988b. The suspension of feeds in aerated rearing tanks: The effect of tank geometry and aerator design. Aquacultural Engineering, 7: 379395.

Backhurst, J.R., Chaalal, O., \& Harker, J.H. 1989. Optimum aeration rates for the suspension of larval feeds. Aquacultural Engineering, 8: 217- 221.

Becker, W. 2004. Microalgae for Aquaculture: The Nutritional Value of Microalgae for Aquaculture. in A. Richmond, editor. Handbook of Microaga Culture: Biotechnology and Applied Phycology. Blackwell Publishing, Australia, p. 380- 382.

Borowitzka, M. 1997. Microalgae for aquaculture: Opportunities and constraints. Journal of Applied Phycology, 9: 393- 401.

Cognie, B., Barillé, L., Massé, G., \& Beninger, P.G. 2003. Selection and processing of large suspended algae in the oyster Crassostrea gigas. Mar. Ecol. Prog. Ser., 250: 145- 152.

Duerr, E.O., Molnar, A., \& Sato, V. 1998. Cultured microalgae as aquaculture feeds. Journal of Marine Biotechnology, 6: 65- 70.

Holme, M.- H., Zeng, C., \& Southgate, P.C. 2009. A review of recent progress toward development of a formulated microbound diet for mud crab, Scylla serrata, larvae and their nutritional requirements. Aquaculture, 286: 164- 175.

Ingersoll, C.G., Kernaghan, N.J., Gross, T.S., Bishop, C.D., Wang, N., \& Roberts, A. 2006. Laboratory toxicity testing with freshwater mussels. In Farris JL, van Hassel JH, eds. Freshwater Bivalve Ecotoxicology.SETAC, Pensacola, FL, USA, p. 95-134.

Joan Holt, G., Faulk, C.K., \&Schwarz, M.H. 2007. A review of the larviculture of cobia Rachycentron canadum, a warm water marine fish. Aquaculture, 268: 181- 187. 
Kach, D. \& Ward, J. 2008. The role of marine aggregates in the ingestion of picoplanktonsize particles by suspension- feeding molluscs. Marine Biology, 153: 797- 805.

Knauer, J. \& Southgate, P.C. 1999. A Review of the Nutritional Requirements of Bivalves and the Development of Alternative and Artificial Diets for Bivalve Aquaculture. Reviews in Fisheries Science, 7: 241- 280.

Knuckey, R.M., Brown, M.R., Robert, R., \& Frampton, D.M.F. 2006. Production of microalgal concentrates by flocculation and their assessment as aquaculture feeds. Aquacultural Engineering, 35: 300313.

Langdon, C. 2003. Microparticle types for delivering nutrients to marine fish larvae. Aquaculture, 227: 259- 275.

Martínez-Fernández, E., Acosta-Salmón, H., \& Rangel- Dávalos, C. 2004. Ingestion and digestion of 10 species of microalgae by winged pearl oyster Pteria sterna (Gould, 1851) larvae. Aquaculture, 230: 417- 423.

Palmtag, M.R., Faulk, C.K., \& Holt, G.J. 2006. Highly Unsaturated Fatty Acid Composition of Rotifers (Brachionus plicatilis) and Artemia Fed Various Enrichments. Journal of the Wor Id Aquaculture Society, 37: 126131.

Pfeiffer, T.J. \& Ludwig, G.M. 2007. Small- Scale System for the Mass Production of Rotifers
Using Algal Paste. North American Journal of Aquaculture, 69: 239- 243.

Ponis, E., Probert, I., Véron, B., Mathieu, M., \& Robert, R. 2006b. New microalgae for the Pacific oyster Crassostrea gigas larvae. Aquaculture, 253: 618- 627.

Ponis, E., Probert, I., Véron, B., Le Coz, J.R., Mathieu, M., \& Robert, R. 2006a. Nutritional value of six Pavlovophyceae for Crassostrea gigas and Pecten maximus larvae. Aquaculture, 254: 544- 553.

Riebesell, U. 1991. Particle aggregation during a diatom bloom. I. Physical aspects. Mar. Ecol. hog. Ser., 66: 213-280.

Sieracki, C.K., Sieracki, M.E. \& Yentsch, C.S. 1998. An imaging in-flow system for automated analysis of marine microplankton. Mar. Ecol. Prog. Ser., 168: 28596.

Wang, N., Ingersoll, C.G., Greer, I.E., Hardesty, D.K., Ivey, C.D., \& Kunz, J.L., et al. 2007. Chronic toxicity of copper and ammonia to juvenile freshwater mussels (unionidae). Environmental Toxicology and Chemistry, 26(10): 2,048- 2,056.

Zelaya, O., Davis, D.A. \& Rouse, D.B. 2007. The Influence of Artemia and Algal Supplements during the Nursery Phase of Rearing Pacific White Shrimp, Litopenaeus vannamei. Journal of the World Aquaculture Society, 38: 486- 496. 